Journal of Materials and Environmental Sciences

ISSN : 2028-2508

CODEN : JMESCN

Copyright $\odot 2017$

niversity of Mohammed Premie
J. Mater. Environ. Sci., 2017, Volume 8, Issue 12, Page 4510-4522

http://www.jmaterenvironsci.com

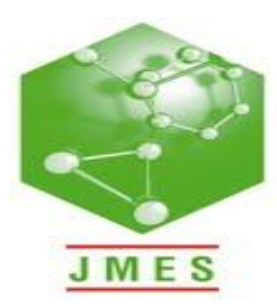

\title{
The contribution to hydrogeological and hydrochemical knowledge of the aquifers in the East side of Bouhachem area (Tetouan, Morocco).
}

\author{
Redouan ALILOUCH ${ }^{1}$, Karim EL MORABITI ${ }^{1}$ and Abdel Aziz EL MRIHI ${ }^{\mathbf{1}}$ \\ 1. Department of Geology, Faculty of Science, Abdelmalek Essaadi University, B.P. 2121 Tetouan, Morocco
}

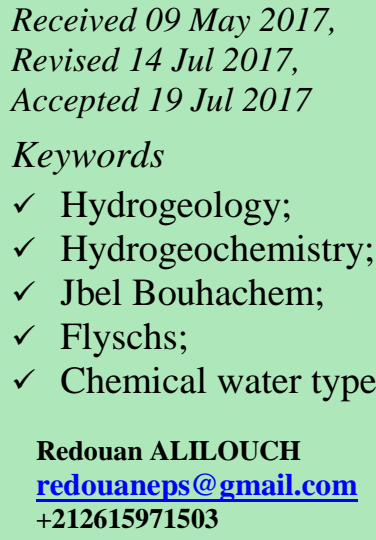

\begin{abstract}
The contribution to the hydrogeological and hydrochimical knowledge of the aquifers of the East zone of Bouhachem area constitutes the main aim of this study. This work aims: i) to make the inventory of water supply points of the area, ii) to study their relationship with the detrital and carbonated formations, as well as with the neighbouring some ones and iii) to establish the water facies's quality and the features of these aquifers. The study area is located in the north of Morocco, in the septentrional Rif and it belongs to the flyschs nappes and the calcareous dorsal. In the hydrogeogical point of view, the East zone of Jbel Bouhachem is characterized by a large drainage basin (catchment area of Moulay-Bouchta "Wadi"), which is characterized in turn by aquifers of different lithological nature.
\end{abstract}

\section{Introduction}

Water is much more than just a human need; it is the most vital element for life [9]. It has become a strategic global issue, the management of which must imperatively integrate itself into a political perspective of sustainable development. Some say it will be, in the third millennium, an issue of wars as oil has been and still is today [2, 11]. The water reserves per capita, which border already the threshold of the stress with 1000 $\mathrm{m} 3 / \mathrm{hab} / \mathrm{yr}$, would be in 2020 around $500 \mathrm{~m} 3 / \mathrm{hab} / \mathrm{yr}$. [1]. Groundwater is the largest and most important water resource in Africa [13, 14]. It is often more reliable, in closer proximity to users, less vulnerable to pollution, and more resilient to climate variability than surface water $[12,13]$. In this context, Morocco is a country which relatively has an important water resources. It profits indeed from many natural potentialities as mountainous water tower with broad spaces of infiltration with tops covered by snow, and important underground layers.

The water resources exploited by the population of the study area are starting to be exceeded by the requests and are very unequally distributed between the communes. This justifies the importance of water as a paramount element for the socio-economic development of an area and increases the interest of a hydrogeological, hydro geochemical and bacteriological knowledge of the sources of water. It is in this general context that the present study is made. Its principal goal is the contribution to the hydrogeologic and hydrochimic knowledge of the water of the Jebel Bouhachem flyschs nappes. This is based on:

- the hydro-climatic study of the area.

- the inventory of water sources and the study of their relationships with the detrital formations and the neighbouring formations.

- the study of water chemical facies characteristics and water's quality of the aquifers in the area.

1.1 Geographical and socio-economic characteristics of the study area

Of a surface of 8000 ha, of which 40 to $50 \%$ belongs to the forest field, the Bouhachem area is located at the north of Morocco, in the northern Rif between the following Lambert coordinates $\left(X_{\operatorname{Min}}=486000 \mathrm{~m}\right.$ and $X_{\text {Max }}=$ 
$513000 \mathrm{~m})$ and $\left(\mathrm{Y}_{\mathrm{Min}}=512000\right.$ and $\left.\mathrm{Y}_{\mathrm{Max}}=528000 \mathrm{~m}\right)$ (see figure 1). This latter is characterized by an important biodiversity which classifies it among the national parks most snuffed by tourism. In the geological point of view, it belongs to the flyschs nappes and calcareous dorsal, which form part of the Riffian chain in the southeast of Tetouan city. The region of Bouhachem include three provinces: Chefchaoun, Larache and Tetouan. It is about 41837 in habitants in rural environment including 7953 households distributed over 4 rural communes: the Western zone consisting of Tazroute ( Moulay Abdsalame Center, Caïdat Bni Arouss, Province of Larache); Bni leït, and the east zone is represented by El Oued and Al Hamra (Bni Hassan, Province of Tetouan) .

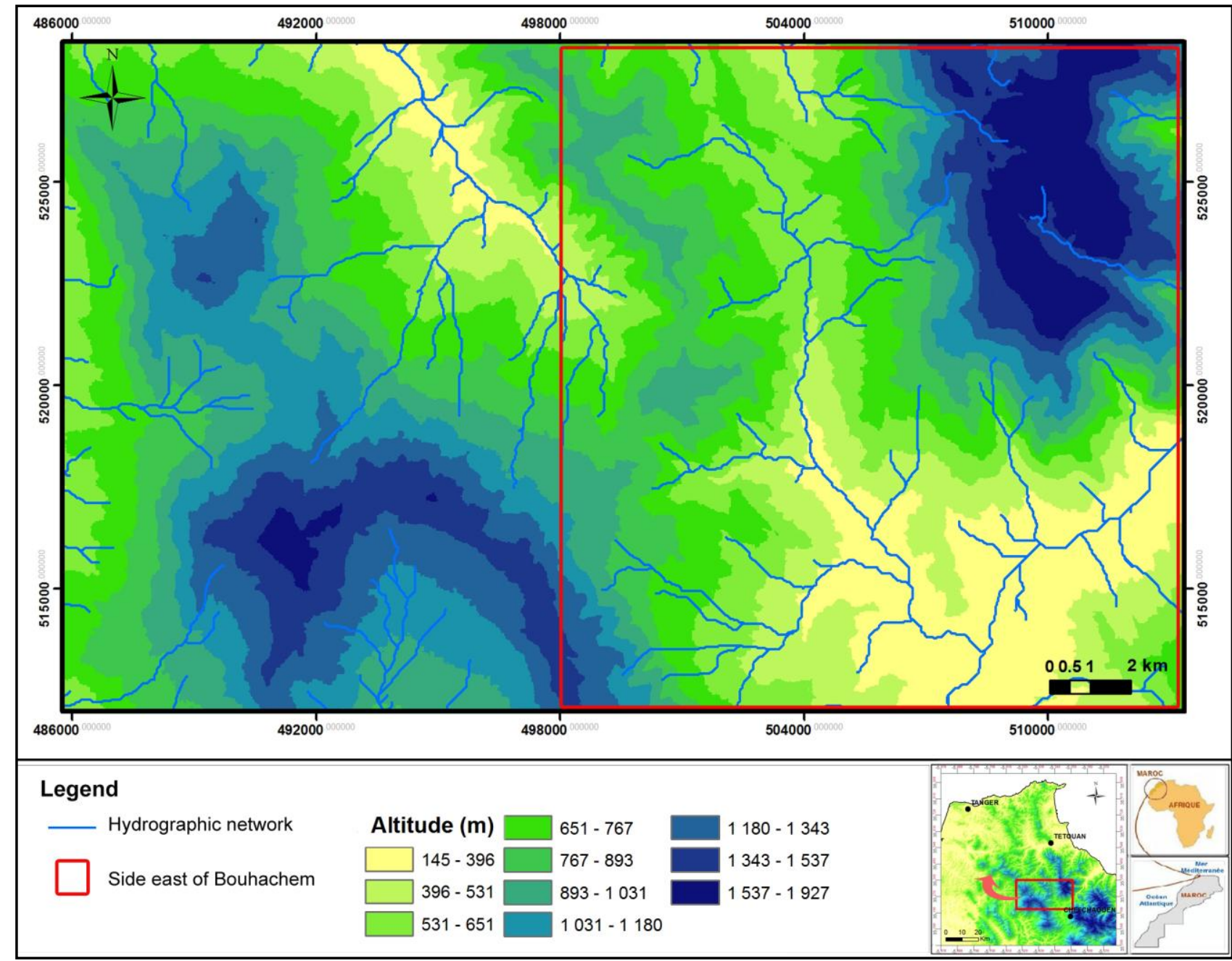

Figure 1: Hypsometric map showing the geographical location of the study area.

\subsection{Hydoclimatic characteristics}

The East side of Bouhachem comprises a large catchment area (C.A of Moulay-Bouchta "Wadi"), as well as others under-basins and several small "wadis" or temporary or torrential affluent. The latter drains great quantities of water towards the zones of infiltration, which play a central role in the feeding and the refeeding of the aquifers of the area. It is necessary also to note the existence of some ponds and lakes at the top of Jbel Bouhachem. The Riffian climate of the Mediterranean type is characterized by a hot and dry summer, while the winter is sub-humid and cold.

\subsection{Geological and hydrogeologic context}

\subsubsection{Geological context}

The area is located in part in the internal domain (calcareous dorsal), in part in the external one (unit of Tanger) and in the flyschs nappes of the Riffian chain $[19,23,27]$ (figure 2). This latter is characterized by great structural complexity and by several thrusts contacts within the geological units [7]. 
- The internal domain of the Rifian chain is represented by the calcareous dorsal which include many units as: i) the unit of Bettara (sandstone, conglomerates, and marls of Oligocene age overlying lower Lias lime-stones at the base,), ii) the unit of Arifane (with at the top an Oligocene terrigenous formation made by sandstone, conglomerate and marl, lying over thick basal Triasic-Liasic massive carbonated formation, iii) El Babat nappe (Triasic-Liasic formation made by red detrital formation, dolostone and white massive limestone with at the top Paleogene formation made by polygenic conglomerates), iv) the unit of Abijouene (with Oligocene marl, Eocene breccias, and Rhaetian to Hettangien massive Carbonated formation at the base), v) Hafa Ferkennix nappe (with at top Oligocene formation made by Sandstones, Conglomerates and marls: and Triasic-Hettagian massive dolostone and Sinemurien massive white Limestones partially dolomitised), the unit of Lfahsa (Jbel Lakraa nappe) and the unit of Majjou (Jbel.Tazoute nappe)[4].

- In the area of study, the external domain is represented by the Tanger Unit which is characterized by Upper Cretaceous succession (At top,we find some marl interbeded with microbreccias and, in bottom, we find clay, siltstone and some thick- layerd siliceous calcilutite grading to flint(Silex). It is largely overthrusted by the flyschs nappes and the internal domain $[4,5]$.

- The flyschs nappes overthrust the external zones. They are formed by the Beni Ider nappe ( with Eocene calcarenites and Oligocene micaceous sandstones), the Melloussa nappe (the succession is characterized by schisto-quartzite flyschs of Albian-Aptian age, phthanites of Cenomanian age and upper Cretaceous "marno-schist") and the Numidian nappe (characterized by Numidian sandstone of probable Aquitanian in age) which rest tectonically on the previous nappe by a flat tectonic contact or with slightly dipping contact towards the West and/or East on the various terms of the unit of Tanger $[5,6,10,23]$. It is always in the higher position compared to other Flysch units and affected by N120$140 \mathrm{E}$ normal faults dipping towards the SW or NE [10].

- The Predorsalian unit (marls with thin bedded sandstones flysch sequence and Numidian-like sandstone of Oligocene age and marl-limestone with Saccocoma of Malm age). It corresponds to the outcrops which are trapped between the internal and external zones of the Rif and the Betic Cordilleras [7].

The two principal NE and SW slopes of Bouhachem are characterized by the presence of glacis (a paved slope) and the rock peaks more or less covered by a dwarf vegetation.

\subsubsection{Hydrogeological context.}

The watersheds of the area are characterized by aquifer units of different lithological nature. The base of these water underground sheets is generally delimited by an impermeable layer of the Bni-Ider nappe and the Upper Cretaceous succession of the Tanger unit. This later corresponds to plastic coloured marly-clayey material, with sandy turbidities, limestone or mixed,. The materials of the Flyschs units with sandstone and pelite are not very plastic, however, instabilities of the ground are frequent. The presence of a dense network of fractures supports the installation, in wet season, of the perched water sheets within the initially impermeable formations (figure 2).

\section{Materials and methods}

\subsection{Data and materials}

For the study of the area we used four topographic maps on scale 1/50000 (Ministry of agriculture) [8, 10, 15, 16]; two geological maps on scales 1/500000 and 1/50000 (Ministry of energy and mines,) [4, 22]; a structural map on scale 1/500000 (Ministry of energy and mines) [6]; climatological data and contact of the weather stations (Agency of the Hydraulic Basin of Loukkous in Tetouan city).

\subsection{Methodology}

In this work, the field thorough analysis plays a central role and constitutes a basic stage for the scientific approach of the topic. Here, it is about a methodology of scientific research (OHERIC). We proceeded by:

\subsubsection{Field work}

In the field, we started with the geographical recognition of the zone of study using an adapted cartographic base; general geological recognition of the sector of study and the inventory of the existing water supply points in the area. Then, we determined the contact and altitudes of the water supply points, to measure the physicochemical parameters on the ground (electric conductivity, temperature and $\mathrm{pH}$ ), the flows of the sources, 
the piezometric levels of the wells and to finish by a systematic sampling. Finally, we took pictures and established schematic cross-sections for showing the deformations and the contacts geometry between the geological formations which are behind the emergence of these water sources. These measurements were carried out during a first dry period (June, July and August of the year 2013 and 2014) and a second wet time (December, January and April 2013 and 2014).

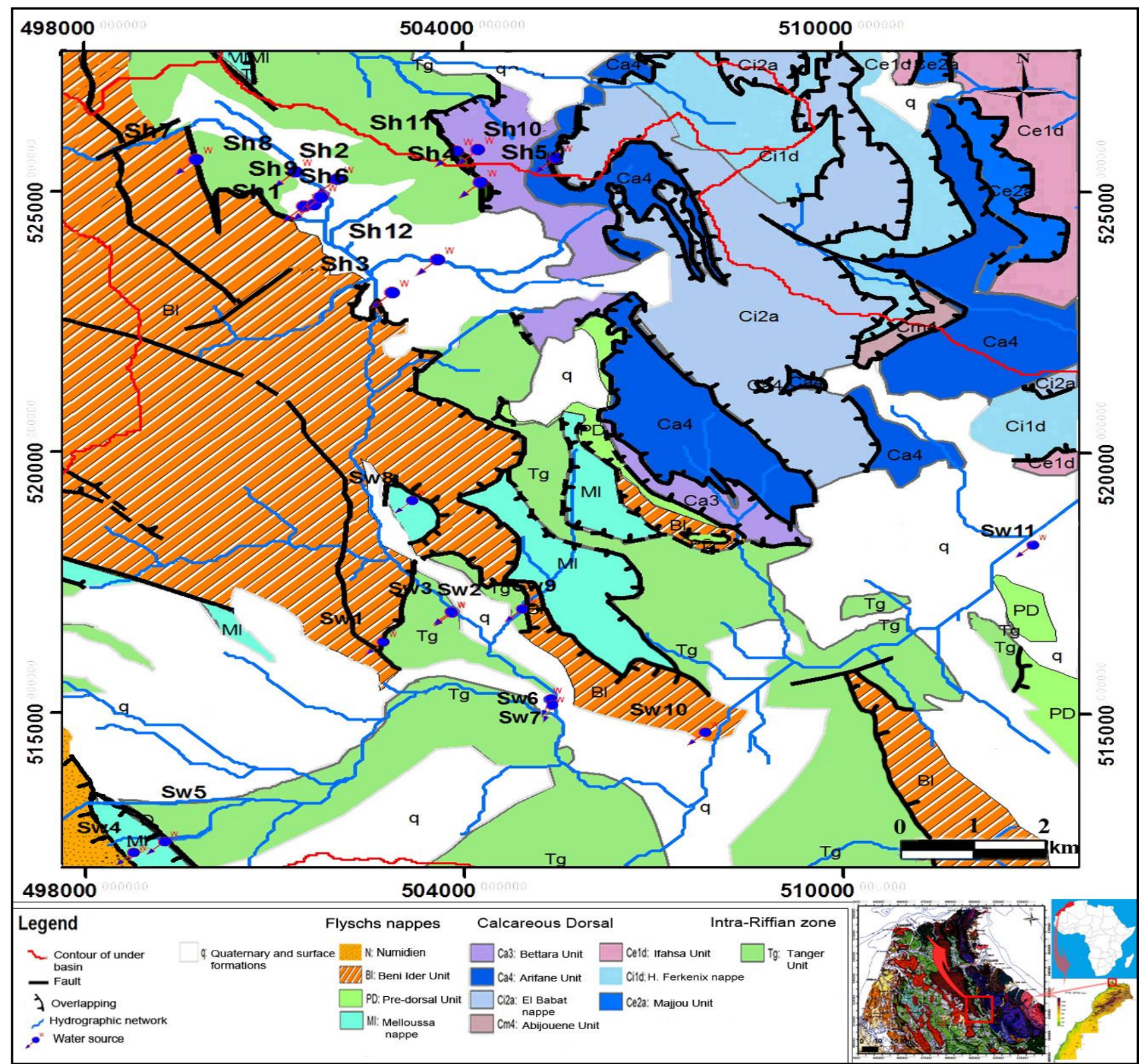

Figure 2: Structural sketch map with localization of water supply points in the East area of Bouhachem

\subsection{2 laboratory and office work}

The water's chemical and bacteriological analyses are carried out in the Transfer of water's Technologies center (C.T.T) of the agency of the hydraulic basin of Loukous, at the regional Laboratory of environment within the Faculty of Science, Abdel Malek Essaadi University in Tetouan and at a Mineral Water Company in Chefchaouen. The chemical and bacteriological parameters were analyzed in the laboratory according to the protocol of analysis of Rodier and al., 2009 [9, 21].The classification and the comparison of groundwater of the zone of study are based on the diagrams of Piper and Schöeller-Berkaloff.

The cartography work consists of drawing thematic maps and establishing geological cross-sections crossing various water supply points. This operation was carried out while being based on the data of the topographic, 
geological and structural maps $[4,10,15,16,18]$, compared and confirmed by the observation and the structural study of the various lithological facies and aquiferous systems in the field.

The climatological study uses two principal parameters: precipitations and the temperature. In absence of the weather stations in this area, we took the data of the nearest weather stations (figure 3 ). The evapotranspiration potential was calculated using Thorntwaite method [8, 24, 25].

\section{Results and discussion}

\subsection{Climatic characteristics}

To have representative results, we choose a period of 36 years (from 1972 to 2008), as the World Meteorological Organization counsel. The map of figure 3 indicates the positions of these stations around the sector of study.

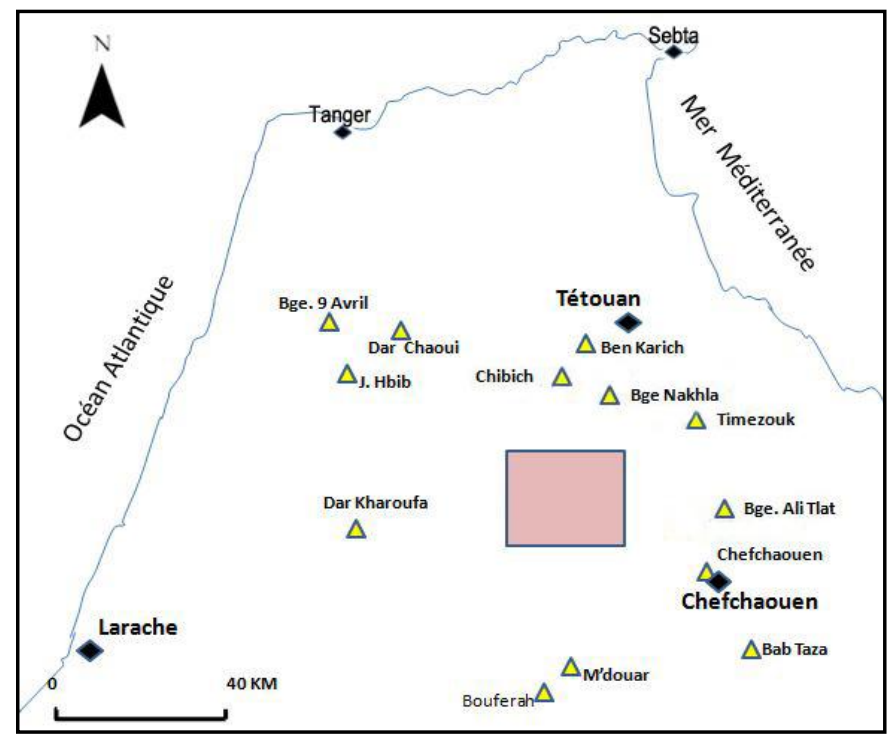

Figure 3: Localization of the weather stations closest to the zone of study

From climatological study of the east side of Bouhachem area based on the climatological data of the nearest weather stations -the Nakhla dam station-; we deduce that the dry period lasts four months and a half. It extends from the mid-May until the end of September. The maximum drought is recorded during the months of July and August (figure 4).

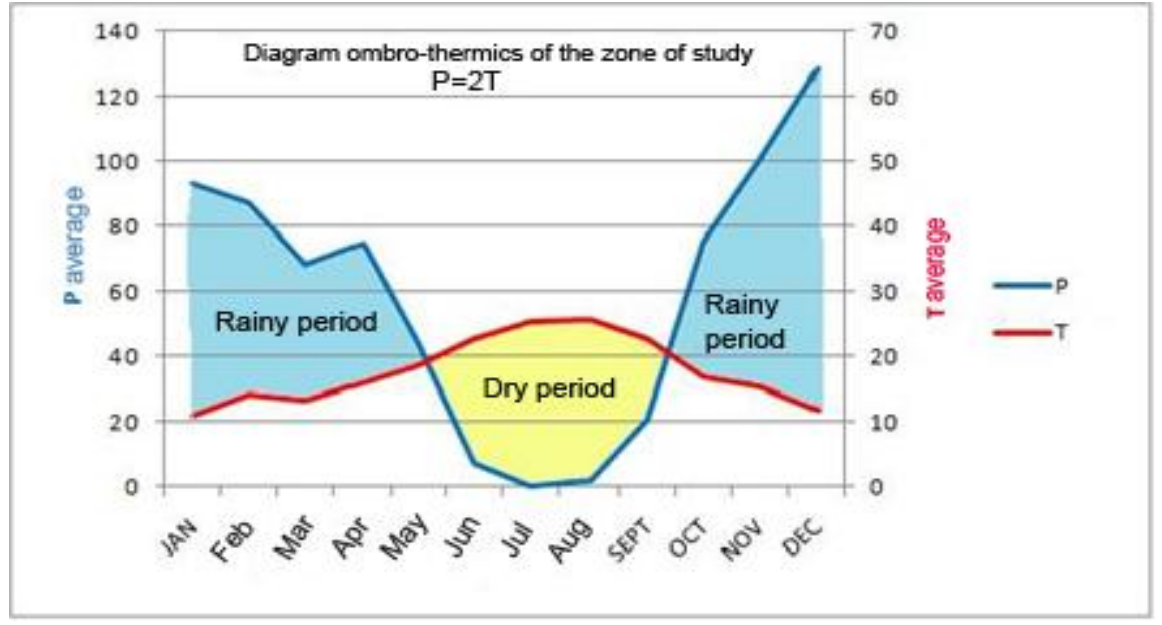

Figure 4: Ombro-thermics diagram of station Nakhla (Period 1972 - 2008).

According to the area pluviometric quotient $(\mathrm{Qp}=79.87)$ (climatic Index of Emberger) and the monthly minimal average temperature $\left(\mathrm{T} \min =7.5^{\circ} \mathrm{C}\right)$; the area is characterized by a Sub-wet bioclimatic stage and a hot/moderate winter (Figure 5). 
Therefore, the east side of Bouhachem is of a subhumid Mediterranean climate, with a moderated-hot winter. Indeed, precipitations that touch the main forest of Bouhachem can exceed $1700 \mathrm{~mm}$ per year, so it's considered as one of the most rainy zones in Morocco (figure 6).

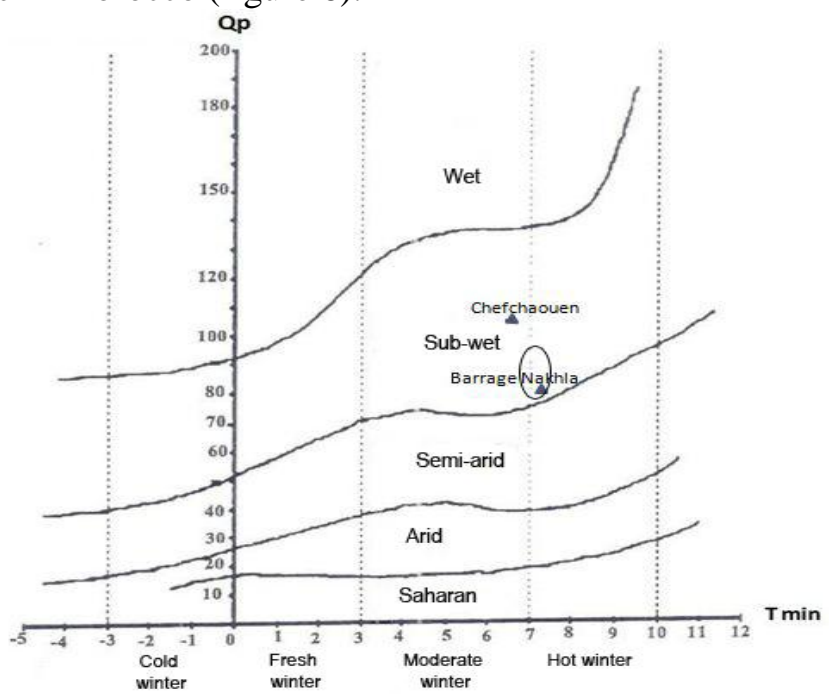

Figure 5: Pluviometric diagram and bioclimatic stages of Emberger.



Figure 6: Map of precipitations (mm) of the East area of Bouhachem 
Several empirical expressions introducing the climatic parameters were established (THORNTHWAITE [24] and TURK [25]) for the evaluation of the real evapotranspiration (ETR) and/or the potential one (ETP). The annual average potential evapotranspiration obtained is $680.51 \mathrm{~mm} / \mathrm{yr}$; the maximum is recorded in July (113.9 $\mathrm{mm})$ and the minimum in January $(17.71 \mathrm{~mm})$. The annual real evapotranspiration (ETR) is estimated about $598.79 \mathrm{~mm} / \mathrm{yr}$; it accounts for almost $86 \%$ of precipitations.

For effective precipitations; the results obtained from the data of the Nakhla station for the period (1983-2000) by the method of TURK give the average of $95.81 \mathrm{~mm} / \mathrm{yr}$, with $13.79 \%$ of the annual average pluviometry.

\subsection{Hydrogeologic characteristics}

The study of the relationship of emergence of the various sources with the geological contacts permit to highlight the hydrogeological framework of the aquifers in the area. We relied on schematic cross-sections crossing the water sources. The orientation of these ones were well chosen, in order to facilitate, as much as possible, the explanation and the analysis of their emergence (figure 7).

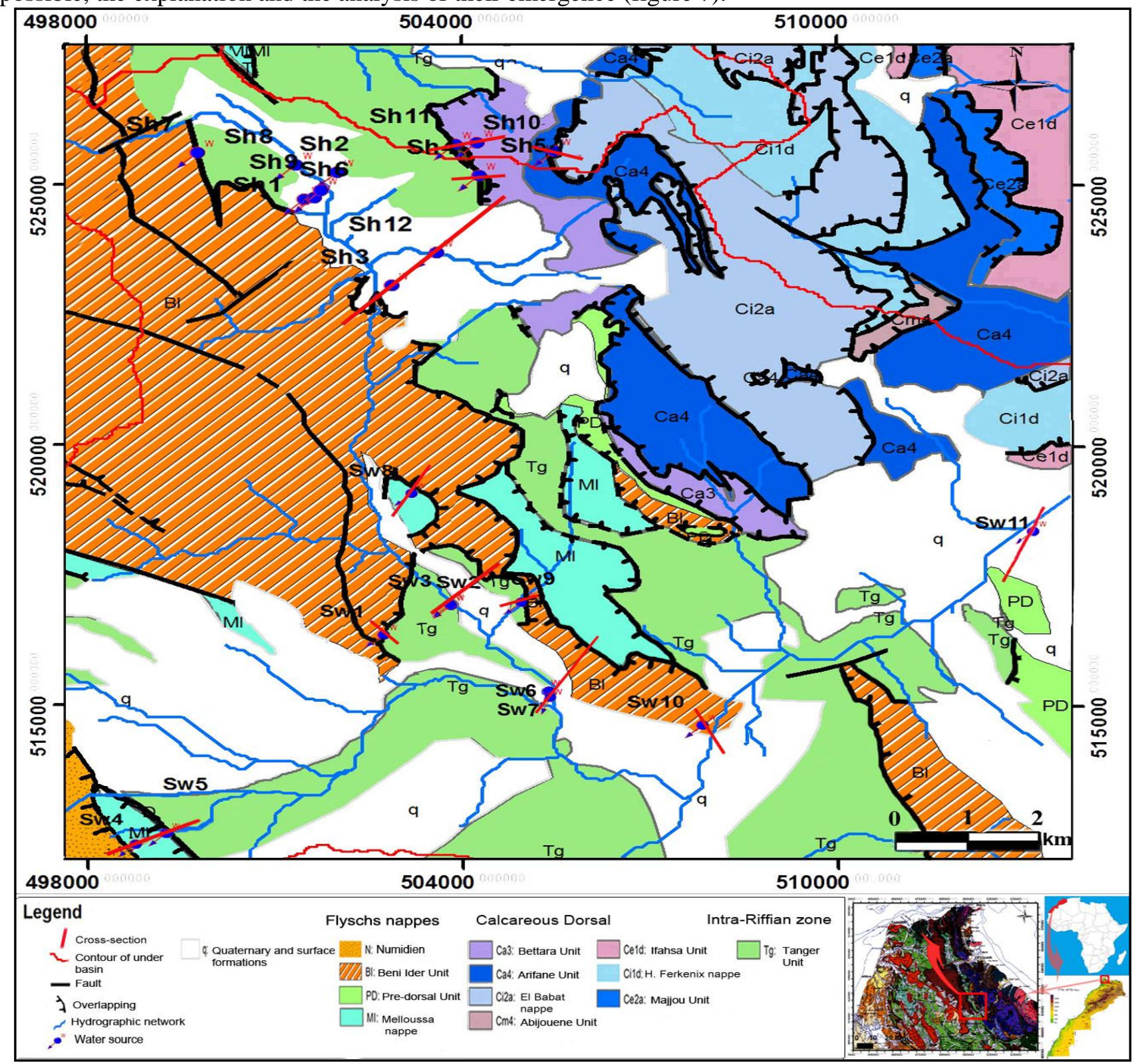

Figure 7: Structural sketch map showing the position of the schematic cross-sections through the sources of water in the area East of Bouhachem.

The sector of study formed by aquifer materials of different lithological nature, which permit to distinguish two types of natural groundwater basins: 
1/ Porous aquifers (Alluvial, sandstone.) where rise the majority of the sources inventoried in this work.

2/ Karstic aquifers in El Hamrae (Mahrech, Afouridine).

The two communes (El Hamrae and El Oued) on the east side of the study area contains two types of aquifer, where 10 sources and 13 wells has been inventoried. The sources of water of these two communes spout out exactly in the main tectonic contact which corresponds to thrust between the calcareous dorsal ( Bettara Unit, Majou Unit, Arifane Unit, El Babat Unit) and the flyschs of Bni Ider with an impermeable basal level of the Tanger unit of Upper Cretaceous in age. This later corresponds to, a free carbonate clayey formation with interbedded tick-layered siliceous calcilutite grading to flint. (figure 7) and (figure 8)



(B)

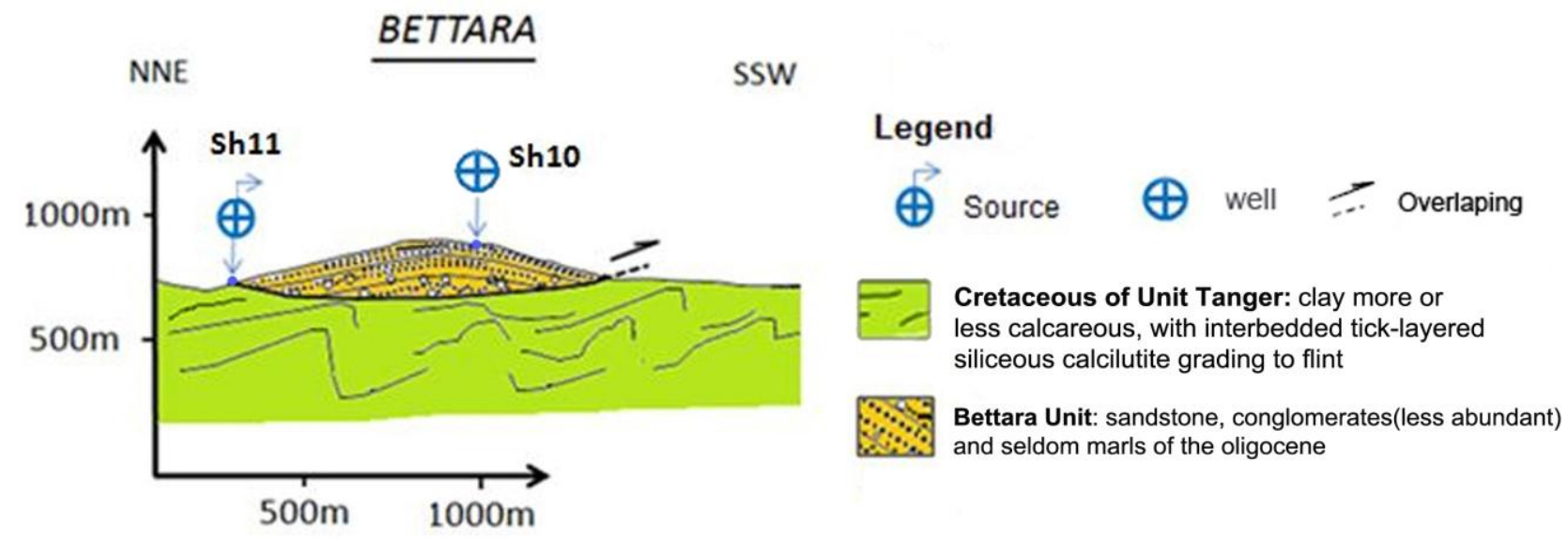

Figure 8: Schematic cross-sections ((a) BETTARA and (b) IFKIRENE) showing the relationship between structure and water sources.

\subsection{Physicochemical characteristics}

In order to direct the use of water to different uses, in particular human, agricultural and industrial consumption; its quality should initially be known, then its state of deterioration by contamination, when it exists, or facility to contaminate itself.

For water characterization from the physicochemical and bacteriological point of view, one bases oneself on the quantification of underground water quality in the aquiferous unit, while referring to the physicochemical and bacteriological characteristics which water for human consumption must have. The majority of the sources of water of the area of study have a low flow, but they are of perennial and cold type. They spout out in mechanical contacts between an aquifer and another "aquiclude" which plays the part of substratum of unconfined water. 


\subsubsection{Physical characters}

The Moroccan regulation fixes for water for human consumption the maximum limit of conductivity in 2700 $\mu \mathrm{S} / \mathrm{cm}$. The evolution of the conductivity measured in the sources of two communes oscillates between the extreme value of $1649 \mu \mathrm{S} / \mathrm{cm}$ recorded in the well Sw10, and the minimal value of $98.7 \mu \mathrm{S} / \mathrm{cm}$ recorded in the source (Sw5), and with an average of $675 \mu \mathrm{S} / \mathrm{cm}$. Therefore, water of these sources is fairly mineral-bearing (mineralisation ranging between 500 and $1000 \mathrm{mg} / \mathrm{L}$ ) (Table 2 and 3). The $\mathrm{pH}$ of natural water depends on the free carbon dioxide concentration, inter alia components, and increases with the temperature. For human consumption, the World health organization admits for minimal and maximum limit $\mathrm{pH}$ of groundwater 6.5 and 8.5 , respectively. The 23 water supply points show a normal $\mathrm{pH}$, i.e. in the standards, with an average of $\mathrm{pH}=7.08$. The values of $\mathrm{pH}$ are, however, variable from one point to another. The highest value recorded is about 7.9; the lowest values measured are 5.34 and 5.46 specific to the sources of the commune El Oued (Sw4 and Sw5) which rise close to the formation of the Numidian sandstone (acid geological formation), while the others are located in piedmont of the calcareous dorsal (basic geological formation).

Table 2: Physical characters of 11 sources of the area El Oued

\begin{tabular}{|c|c|c|c|c|}
\hline Wording & pH & $\mathbf{c ~ 2 5}^{\circ} \mathbf{C}$ & Piezometric Level & Flow (1/s) \\
\hline Sw1 & 6.6 & 1092 & $491 \mathrm{~m}$ & - \\
\hline Sw2 & 7.2 & 811 & $320 \mathrm{~m}$ & - \\
\hline Sw3 & 7.2 & 772 & $322 \mathrm{~m}$ & - \\
\hline Sw4 & 5.3 & 106 & $685 \mathrm{~m}$ & 0.26 \\
\hline Sw5 & 5.5 & 98.7 & $561 \mathrm{~m}$ & 0.11 \\
\hline Sw6 & 6.9 & 668 & $308 \mathrm{~m}$ & 8.3 \\
\hline Sw7 & 6.2 & 160 & $304 \mathrm{~m}$ & - \\
\hline Sw8 & 7.2 & 763 & $457 \mathrm{~m}$ & - \\
\hline Sw9 & 7.6 & 896 & $383 \mathrm{~m}$ & - \\
\hline Sw10 & 7.4 & 1649 & $302 \mathrm{~m}$ & - \\
\hline Sw11 & 7.6 & 482 & $197 \mathrm{~m}$ & 1.5 \\
\hline
\end{tabular}

Table 3: Physical characters of the sources of the area El Hamrae

\begin{tabular}{|c|c|c|c|c|}
\hline Wording & pH & $\mathbf{c ~ 2 5}^{\circ} \mathbf{C}$ & Piezometric Level & Flow (l/s) \\
\hline Sh1 & 7.44 & 644 & $596 \mathrm{~m}$ & - \\
\hline Sh2 & 7.9 & 475 & $608.5 \mathrm{~m}$ & - \\
\hline Sh3 & 7.7 & 607 & $579 \mathrm{~m}$ & 0.55 \\
\hline Sh4 & 7.85 & 685 & $841 \mathrm{~m}$ & 0.25 \\
\hline Sh5 & 7.78 & 388 & $941 \mathrm{~m}$ & 2 \\
\hline Sh6 & 7.41 & 615 & $595 \mathrm{~m}$ & - \\
\hline Sh7 & 7.2 & 558 & $646 \mathrm{~m}$ & 0.21 \\
\hline Sh8 & 7.23 & 617 & $596.5 \mathrm{~m}$ & - \\
\hline Sh9 & 7.13 & 613 & $593.3 \mathrm{~m}$ & - \\
\hline Sh10 & 6.89 & 1132 & $778 \mathrm{~m}$ & - \\
\hline Sh11 & 6.62 & 1176 & $815 \mathrm{~m}$ & 0.18 \\
\hline Sh12 & 7.4 & 507 & $651 \mathrm{~m}$ & 0.8 \\
\hline
\end{tabular}

\subsubsection{Major and minor chemical elements}

The data of tables 4 and 5 show that the bicarbonates dominate the anions whose average water concentrations of the sources of the two zones are about $284.45 \mathrm{mg} / \mathrm{l}$ (commune El Hamrae) and $201.51 \mathrm{mg} / \mathrm{l}$ (commune El Oued) and the cation dominating is calcium with the highest value recorded is about $176.35 \mathrm{mg} / \mathrm{l}$ (the Sw10 
well) and the lowest values observed are about $8.2 \mathrm{mg} / 1,15.2 \mathrm{mg} / \mathrm{l}$ and $25.1 \mathrm{mg} / \mathrm{l}$ clean with the sources of the commune of El Oued which are further away from the calcareous dorsal (Sw5, Sw4 and Sw7).

Table 4: Concentrations in chemical elements of each source in (mg/l) of EL Hamrae.

\begin{tabular}{|c|c|c|c|c|c|c|c|c|}
\hline The wording & $\mathbf{C a}^{\mathbf{2 +}}$ & $\mathbf{M g}^{\mathbf{2}}$ & $\mathbf{N a}^{+}$ & $\mathbf{K}^{+}$ & $\mathbf{H C O}_{\mathbf{3}}{ }^{-}$ & $\mathbf{C l}^{-}$ & $\mathbf{S O}_{\mathbf{4}}^{\mathbf{2}^{-}}$ & $\mathbf{N O}_{\mathbf{3}}{ }^{-}$ \\
\hline Sw1 & 74.12 & 37.68 & 24.7 & 2.3 & 346 & 42.6 & 22 & 0.1 \\
\hline Sw2 & 124.25 & 4.86 & 13.5 & 2.4 & 232.03 & 95.61 & 31.75 & 0 \\
\hline Sw3 & 124.24 & 7.29 & 16 & 1.4 & 242.25 & 99.26 & 30.25 & 0 \\
\hline Sw4 & 15.2 & 12.53 & 7.5 & 0.6 & 60.5 & 21.2 & 13.4 & 0.17 \\
\hline Sw5 & 8.2 & 6.44 & 3 & 0.4 & 24.5 & 9.23 & 12.2 & 0 \\
\hline Sw6 & 80.4 & 16.2 & 14.5 & 1 & 309.8 & 17.5 & 20.9 & 0.32 \\
\hline Sw7 & 25.1 & 7.73 & 10.6 & 1 & 122 & 14.8 & 12.5 & 0.5 \\
\hline Sw8 & 108.21 & 7.29 & 9.5 & 0.4 & 228.94 & 108.52 & 11.75 & 0 \\
\hline Sw9 & 80.16 & 8.51 & 34.5 & 7.3 & 275.29 & 87.71 & 23.25 & 0 \\
\hline Sw10 & 176.35 & 8.51 & 35.5 & 3.4 & 375.32 & 132.86 & 50.38 & 0.002 \\
\hline Sw11 & 76.15 & 26.73 & 7.3 & 1.4 & 222.91 & 85.61 & 34.13 & 0 \\
\hline
\end{tabular}

Table 5: Concentrations in chemical elements of each source in (mg/l) of El Oued

\begin{tabular}{|c|c|c|c|c|c|c|c|c|}
\hline The wording & $\mathbf{C a}^{2+}$ & $\mathbf{M g}^{\mathbf{2 +}}$ & $\mathbf{N a}^{+}$ & $\mathbf{K}^{+}$ & $\mathbf{H C O}_{\mathbf{3}}{ }^{-}$ & $\mathbf{C l}^{-}$ & $\mathbf{S O}_{\mathbf{4}}{ }^{2-}$ & $\mathbf{N O}_{\mathbf{3}}{ }^{-}$ \\
\hline Sh1 & 84.17 & 15.79 & 28.2 & 1.7 & 288.66 & 35.08 & 49.75 & 0 \\
\hline Sh2 & 80.16 & 10.94 & 22.4 & 1.2 & 290.79 & 22.35 & 17.63 & 0 \\
\hline Sh3 & 112.22 & 10.94 & 11 & 0.8 & 354.3 & 26.99 & 14.38 & 0 \\
\hline Sh4 & 116.23 & 8.51 & 12 & 0.9 & 350.05 & 32.9 & 12.13 & 0 \\
\hline Sh5 & 64.13 & 25.51 & 3.5 & 0.6 & 266.71 & 25.08 & 10.63 & 0 \\
\hline Sh6 & 78.16 & 14.58 & 19.8 & 1.8 & 285 & 29.11 & 20.2 & 0 \\
\hline Sh7 & 89 & 16.51 & 20.12 & 1.4 & 255.2 & 58.8 & 15.04 & 0 \\
\hline Sh8 & 71 & 12.84 & 19.4 & 1.5 & 235.3 & 29.61 & 21.3 & 0 \\
\hline Sh9 & 60 & 18.3 & 19.7 & 1.2 & 215.3 & 28.69 & 33.27 & 0 \\
\hline Sh10 & 114 & 12.28 & 21 & 1 & 321.16 & 55.6 & 8.49 & 0 \\
\hline Sh11 & 115 & 12.89 & 19.5 & 2.2 & 312.6 & 56 & 22 & 0 \\
\hline Sh12 & 79.54 & 10.09 & 10.4 & 0.7 & 238.32 & 29.2 & 21 & 0 \\
\hline
\end{tabular}

\subsubsection{Water type}

The Piper Diagrams $[3,20]$ and Schöeller-berkaloff (figure 9 and 10) affirm that the groundwater of the zones (El Hamrae and El Oued) have a predominance of facies bicarbonated-calcic and magnesian and also Chlorinated and sulphated calcic (source: Sw5). These data reveal the existence of the routes or transits through the geological layers of the following sector of study:

- purely calcium-bicarbonated groundwater path, having a short run time in the formations of the calcareous dorsal;

- bicarbonated-calcic groundwater path, having a long run time in the formations of the calcareous dorsal and influenced by the interchange with water of the adjacent Beni Ider formations;

- purely Chlorinated and sulphated calcic groundwater path, having a short run time in the formations of the Numidian sandstone and cretaceous of the Tanger unit ;

- chlorinate-calcic groundwater path influenced by the contact with water with bicarbonatedcalcic and magnesian predominance, revealing a bicarbonate high rate; 


\subsubsection{Water hardness}

The water hardness of the sources of the communes El Hamrae and El Oued oscillates between soft (sources Sw4, Sw5 and Sw7 HT <2.8), enough lasts $(4.4<\mathrm{TH}<6.6)$, and lasts $(6.6<\mathrm{TH}<8.4)$ (figure 11).

Generally these sources, characterized by water free from nitrate, have a good minerality which is at the same time pure and light.
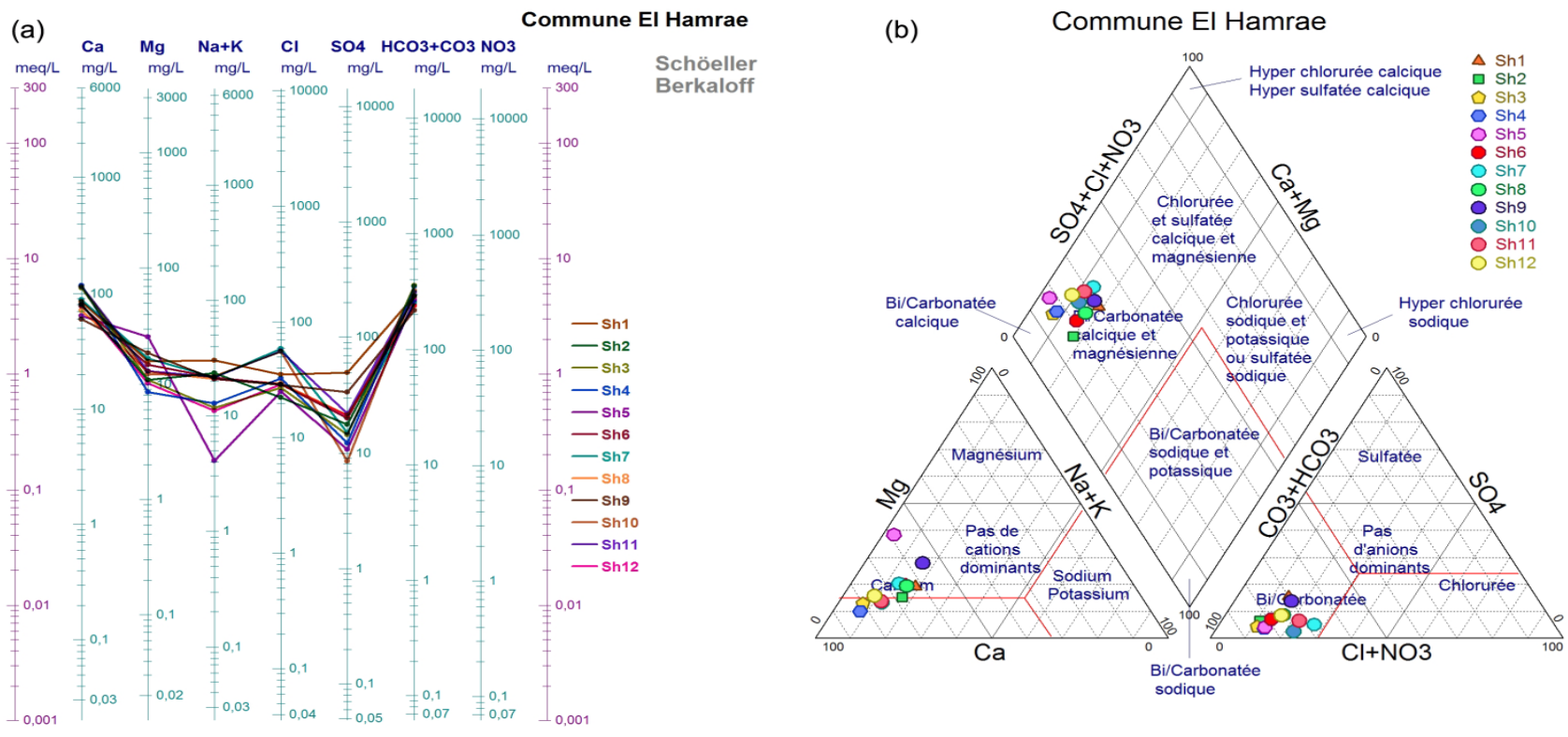

Figure 9: (a) semi-logarithmic diagram of Schöeller-berkaloff and (b) Triangular diagram of Piper represent the water facies of the sources of El Hamrae area
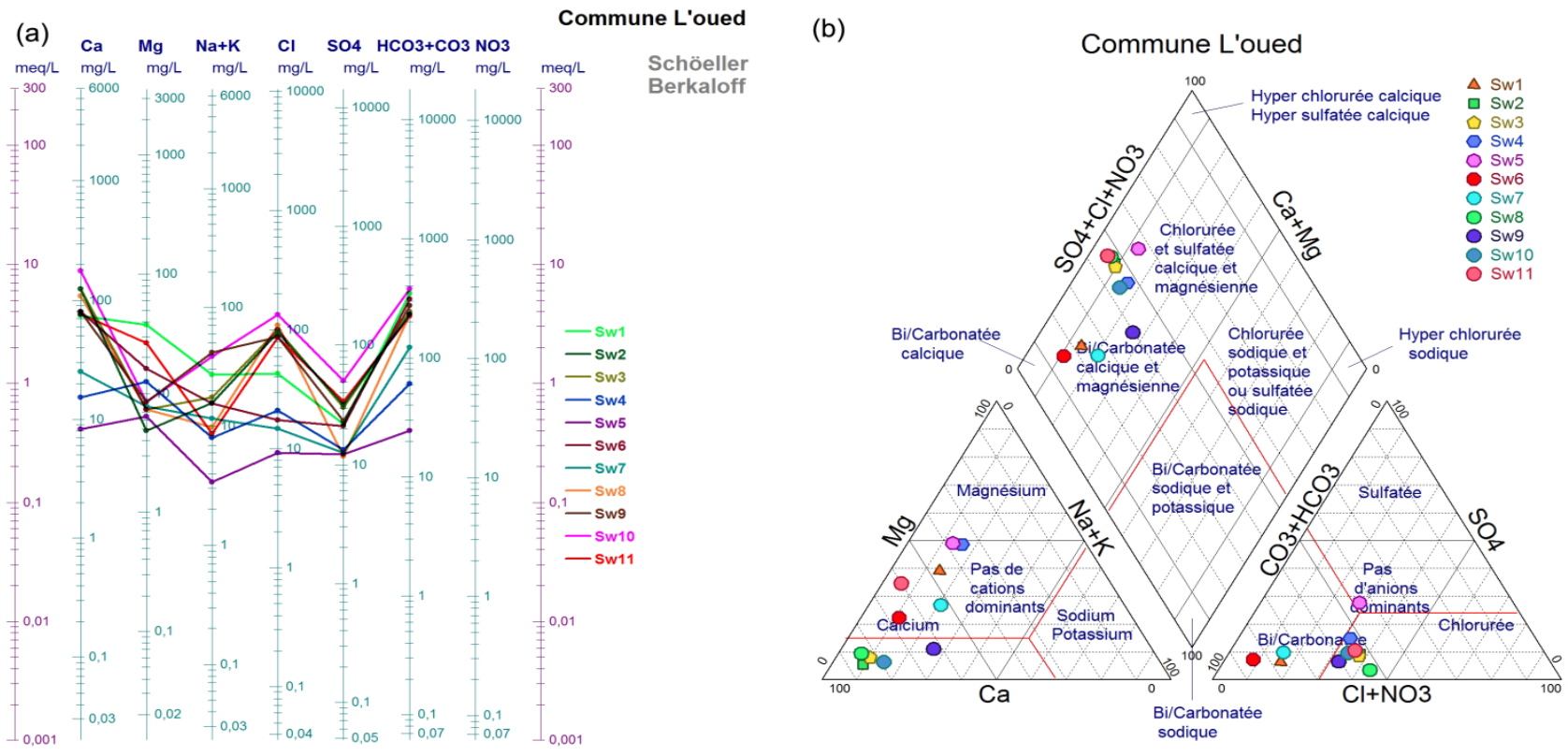

Figure 10: (a) semi-logarithmic diagram of Schöeller-berkaloff and (b) Triangular diagram of Piper represent the water facies of the sources of El Oued area 


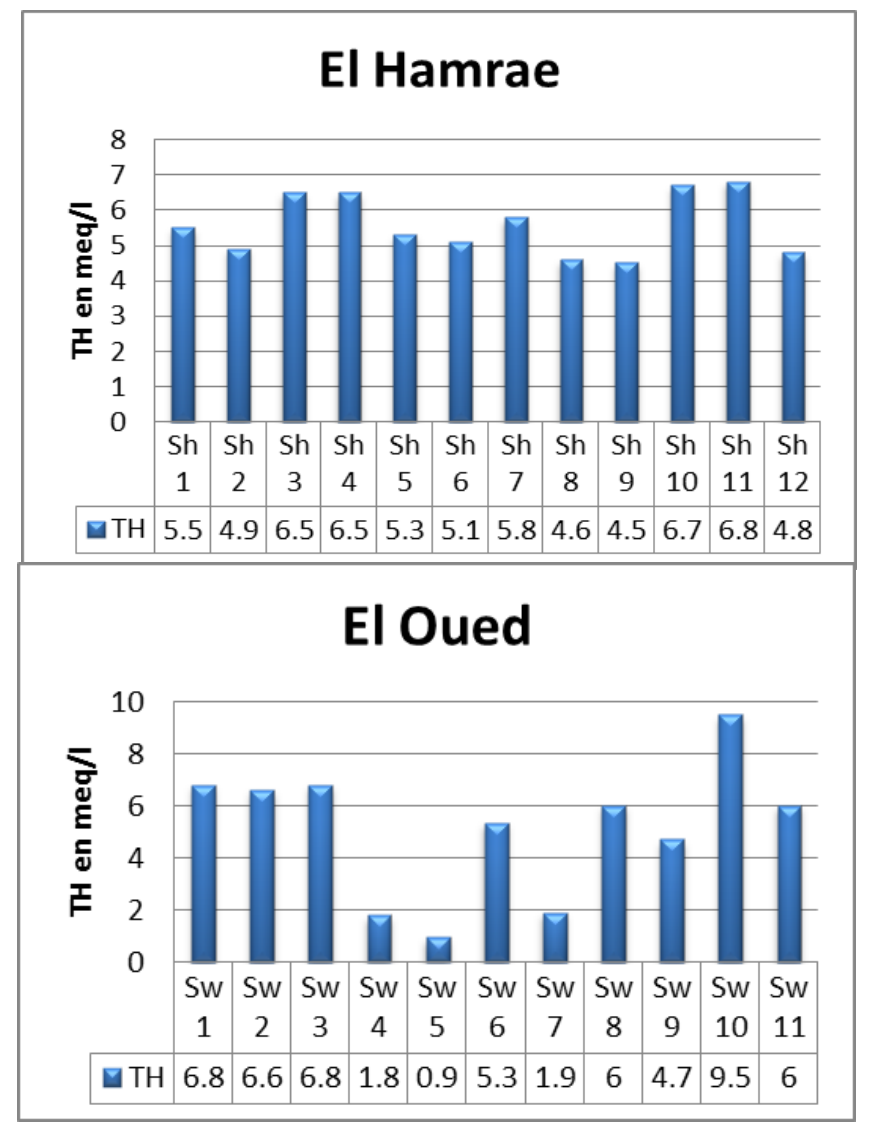

Figure 11: Histograms of hardness water

\subsection{Bacteriological characteristics}

The water bacteriological analyses of the sources reveal that the aquifers of the sector-object of study have an important purifying power. Generally, the contamination of the sources does not exceed the standards except in some wells and sources which are abandoned in the open air and used in the irrigation. The results of the bacteriological analyses reveal the presence of the indicating germs of fecal contamination (figure 13).
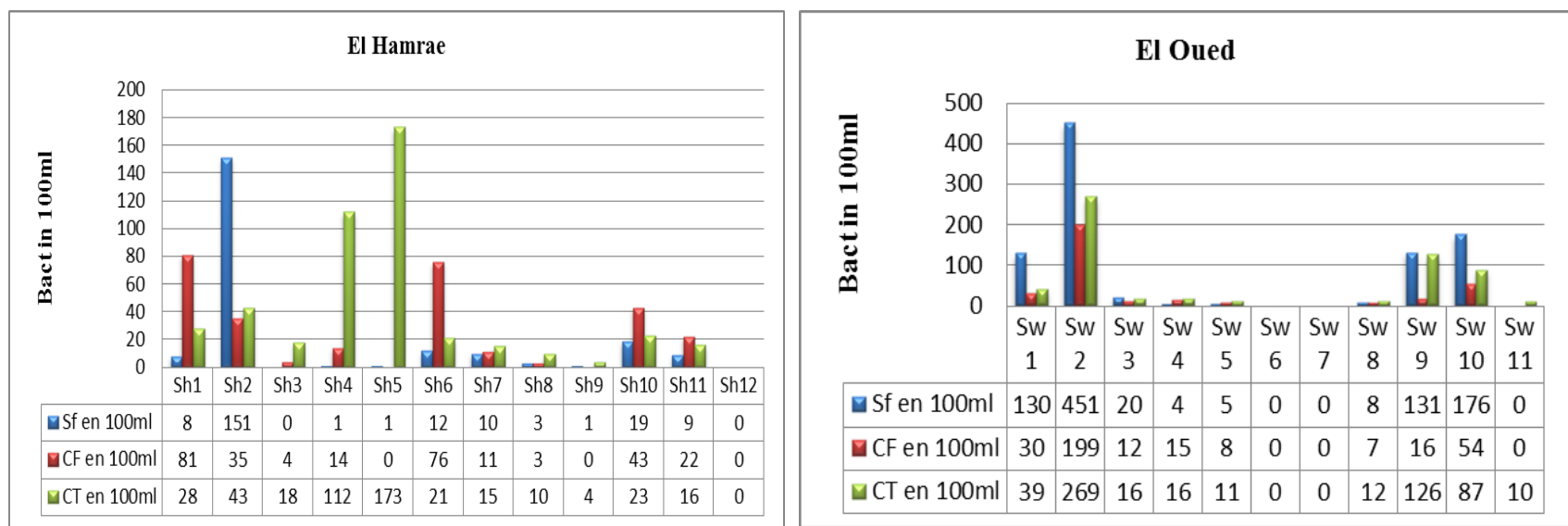

Figure 12: Number of the fecal Streptococci and Coliforms' in the water of the sources of the sector-object of study

\section{Conclusion}

The aquifers located East of Bouhachem area are characterized by different lithological nature from one zone to another. They have an important hydrobiologic behavior. The sources of water rise because of abnormal tectonic contact between two geological formations (an aquifer at the top and another aquiclude forming at the base); or because of normal faults affecting the aquifer. They are of perennial type and are characterized by a generally average flow with weak. The water facies of the area of study are with calcic and magnesian 
bicarbonate predominance. Generally, the water of the area of Bouhachem is fairly hard with soft and very good quality. These sources of water of the area play a central role in the satisfaction of the drinkable water requirements, in irrigation and in domestic use.

\section{References}

1. Agoussine M., Bouchaou L., Science et changements planétaires / Sécheresse.15 (2004) 94-187.

2. Bougarne L., Bouchamma El., Ben Abbou M., Bouka H., J. Mater. Environ. Sci. (JMES). 8 (2017) 2296-2301.

3. Chadha D. K., Hydrogeology J. 7 (1999) 431-439

4. Didon J., Hogga A., Haddane M., Serv. Géol. Maroc. (2004).

5. Didon, J. \& Hoyez, B., Soc. Géol. France. 6 (1978) 304-307.

6. Durand-Delga M. Hottinger L. Marçais J., Mattauer M., Milliard Y. et Suter G., Mém.h.ser.Soc.Géol. Fr.

(Livre mémoire ; Fallot P.). (1960-1962) 399-422.

7. Durand Delga M., Ecl. Géol. Helv. 65 (1972) 267-278.

8. El Morabiti K., Thèse de $3^{\text {ème }}$ cycle. Fac. Sci. Tétouan. Maroc. (1991) 217.

9. El Mountassir R., Bennani B., Merzouki H., Benjelloun Touimi G., Boumchita S., Benjelloun Y., Lahrichi A., J. Mater. Environ. Sci. (JMES). 8 (2017) 2288-2295.

10. El Mrihi A., Thèse de Doct. Fac. Sci. Tétouan. Maroc. (2005) 269.

11. Garcia A., Thèse Doct. Univ. Libre de Bruxelles. (2006) 15-16.

12. Lapworth D.J., MacDonald A.M., Tijani M.N., Darling W.G., Gooddy D.C., Bonsor H.C., Araguás-Araguás L., Hydrogeol J. 21 (2013) 673-686.

13. Lapworth D. J.,Nkhuwa D. C. W., Okotto-Okotto J., Pedley S., Stuart M. E., Tijani M. N.,Wright J., Hydrogeol J. (2017) 1-24.

14. MacDonald A.M., Bonsor H. C., Dochartaigh B. E.O. Taylor R. G., IOPscience. 7 (2012)7.

15. Ministère de l'Agriculture et de la Réforme Agraire., Carte topographique: Souk-El Kolla (Echelle 1/50000). Rabat. Maroc. (1972).

16. Ministère de l'Agriculture et de la Réforme Agraire., Carte topographique: Souk Khmis des Beni Arouss (Echelle 1/50000). Rabat. Maroc. (1966).

17. Ministère de l'Agriculture et de la Réforme Agraire., Carte topographique : Souk Larbaa Beni Hassane (Echelle 1/50000). Rabat. Maroc. (1970).

18. Ministère de l'Agriculture et de la Réforme Agraire., Carte topographique du Maroc CHAOUENE (Echelle 1/50000). Rabat. Maroc. (1970).

19. Pique A., éd. Pumag, Rabat. (1994) 284.

20. Piper, A.M., American Geophysical Union. Papers, Hydrology. (1944) 914-923.

21. Rodier J., Bazin C., Broutin J.P., Chambon P., Champsaur H. Rodi L., Water analysis, 9th edit. Dunod, Paris, France. (2009) 1579.

22. Suter G., Carte géologique de la chaîne rifaine. Notes et Mémoires. Serv. Géo. Rabat. Maroc. $n^{\circ} 245 a$. (1970-1977).

23. Suter G., Carte structurale de la chaîne rifaine. Notes et Mémoires. Serv. Géo. Rabat. Maroc, $n^{\circ} 183 .(1965)$.

24. Thornthwaite C.W., Géol. Review. 38 (1948) 55-94.

25. Tribak Y., El Morabiti K., Hlila R., International Journal of Innovation and Applied Studies (IJIAS). 14 (2016) 653-667.

26. Turc L., Ann. Agr. 6 (1955) 5-131.

27. Wildi W., Rev. Géol. Dyn. Géogr. Phys. 24 (1983) 201-297.

(2017) ; http://www.jmaterenvironsci.com 